Article

\title{
Sustainable Indigenous Fishing in the Pre-Contact Caribbean: Evidence and Critical Considerations from Carriacou, Grenada
}

\author{
Christina M. Giovas (ID
}

check for

updates

Citation: Giovas, C.M. Sustainable Indigenous Fishing in the Pre-Contact Caribbean: Evidence and Critical

Considerations from Carriacou,

Grenada. Sustainability 2021, 13, 9152. https://doi.org/10.3390/

su13169152

\section{Academic Editors: Michelle}

J. LeFebvre, Jon M. Erlandson and Scott M. Fitzpatrick

Received: 16 June 2021

Accepted: 7 August 2021

Published: 16 August 2021

Publisher's Note: MDPI stays neutral with regard to jurisdictional claims in published maps and institutional affiliations.

Copyright: (C) 2021 by the author. Licensee MDPI, Basel, Switzerland. This article is an open access article distributed under the terms and conditions of the Creative Commons Attribution (CC BY) license (https:/ / creativecommons.org/licenses/by/ $4.0 /)$.
Department of Archaeology, Simon Fraser University, Burnaby, BC V5A 1S6, Canada; cgiovas@sfu.ca

\begin{abstract}
Multiple studies reveal pre-1492 anthropogenic impacts on Caribbean fisheries that are consistent with overfishing, including changes in targeted prey, shifts in marine habitats exploited, and decreases in the average body size of taxa. At the Indigenous Caribbean village of Sabazan (AD 400-1400) on Carriacou, Lesser Antilles, post-AD 800 declines in fishing, increased mollusk collection, and changes in resource patch emphasis accord with the archaeological correlates of resource depression predicted by foraging theory models from behavioral ecology. Here, I apply foraging theory logic and abundance indices incorporating body size and fish habitat to test the predictions of expanded diet breadth, declining prey body size, and shifts to more distant fishing patches that are typically associated with overfishing. Results uphold a significant decrease in overall fishing, which may be due to habitat change associated with the Medieval Warm Period. Indices of fish size and resource patch use do not meet foraging theory expectations for resource depression, however. Instead, they suggest an absence of resource depression in the Sabazan fishery and at least 600 years of sustainable fishing. I review similar findings for other Caribbean archaeological sites with either negative evidence for fisheries' declines or quantitatively demonstrated sustainable fishing. These sites collectively serve as a critical reminder of the heterogeneous trajectories of Indigenous social-ecological systems in the pre-contact Caribbean and the need for meta-level analyses of the region's ancient fisheries. I discuss the application of the sustainability concept in archaeological studies of fishing and conclude that a more critical, explicit approach to defining and measuring sustainability in ancient fisheries is needed.
\end{abstract}

Keywords: Caribbean; resource depression; anthropogenic impacts; overfishing; resilience; ceramic age; lesser Antilles

\section{Introduction}

Archaeologists, ecologists, and fisheries scientists increasingly recognize that data from archaeological fish assemblages can provide critical knowledge of the health and long-term anthropogenic stressors of past fish populations salient to the sustainability of modern fisheries, which globally are in crisis [1-7]. The relevance of archaeological data has not gone uncontested, however. More than a decade ago, Baisre [8] challenged mounting archaeological evidence that Indigenous peoples diminished marine fisheries across the pre-contact Caribbean. He called into question the methodology of studies supporting this conclusion and argued their findings ignored ecological, social, and cultural factors constraining the technological capacity of pre-contact Indigenous peoples to exploit marine species.

Since then, strong evidence for pre-modern anthropogenic impacts on marine ecosystems continues to grow within the Caribbean $[3,4,9]$. Among the islands, anthropogenic effects are evidenced by declines in the trophic level of exploited fish, reductions in the size of fish and mollusks, and local prey depletion signaled by declining abundances and shifts in the species exploited [9-12]; but see [13,14] for discussion of the interpretive issues in trophic level analyses of archaeological fish assemblages). These phenomena are consistent with the theoretical predictions of overfishing and observed effects in modern fisheries [7,15-17]. Archaeologically, such phenomena are often framed as a form of 
resource depression [18], subject to testing using foraging theory models derived from evolutionary ecology and measures of foraging efficiency, such as abundance indices [19-21]. Baisre's [8] arguments implicitly support the pristine myth — the notion that environments of the Americas remained "unspoilt" until European arrival [22] — and were critiqued by archaeologists and others on several fronts $[13,23,24])$. Nonetheless, he offered a provocative homily on the unevenness of findings for anthropogenic overfishing and the importance of not extrapolating region-wide effects from localized prey depletion.

Indigenous fisheries' impacts were not universally detrimental, however, as suggested by more recent evidence indicating diverse ecological outcomes associated with centuries of Indigenous fishing in the pre-contact Caribbean. Multiple studies now demonstrate sustainable fishing and mollusk collection based on negative evidence for resource depression and size diminution of prey [25-29]. These studies have generally focused on the Ceramic Age (500 BC-1500 AD), a period during which fisher-forager-horticulturists settled the majority of the Caribbean islands, establishing sedentary, long-term villages. In the Lesser Antilles, Ceramic Age peoples relied heavily upon marine ecosystems for protein subsistence, generally emphasizing coral reef, inshore, and littoral resources [30-33].

In this contribution, I focus on the archaeological site of Sabazan (AD 400-1400) on Carriacou, Grenada, where I demonstrate that faunal abundance indices do not meet theoretical expectations for resource depression despite apparent declines in fishing. While diachronic change in the composition and abundance of the fish catch occurs, there is no evidence to support human predation pressure as the driver. The Sabazan site is consequently significant for exemplifying the heterogeneous trajectories of social-ecological systems in the pre-contact Caribbean and conceptual challenges to the notion of sustainability. I detail the negative evidence for resource depression at Sabazan, consider possible causes for apparent sustainability, review other Caribbean sites with similar findings, and note the need for larger-scale studies of the region. I conclude by discussing how the sustainability concept has been applied to ancient fisheries and the variable standards used to substantiate the sustainability of fishing in the past.

\section{Background}

\subsection{Archaeology and Environment}

The Caribbean islands culture area comprises three major archipelagos: the Greater Antilles and the Bahama Archipelago in the north and the Lesser Antilles in the east, the latter forming the boundary between the Caribbean Sea and Atlantic Ocean (Figure 1).

Cuba, Hispaniola, and Puerto Rico were settled first around ca. 4500-4000 BC, probably from the Isthmo-Colombian region by forager populations whose sites are ephemeral and sparsely distributed [34]. After 3300 BC, a second wave of Archaic peoples arrived from northern South America to the Greater Antilles and northern Lesser Antilles, largely bypassing the southern Lesser Antilles [35]. Archaeological evidence indicates that Archaic groups practiced a mixed economy of fishing and foraging, with some cultivation of wild and domestic plants; settlement density is low, and sites show both seasonal and longerterm occupation [36,37]. The Ceramic Age begins ca. 500 BC when Arawak-speaking peoples move from the Lower Orinoco Basin of South America into Puerto Rico and the northern Lesser Antilles, expanding across the region over the ensuing two millennia. Ceramic Age peoples are noted for their long-term sedentary villages, ubiquitous pottery, crop cultivation, and introduction of plants and animals from South America. They exploited both marine and terrestrial animals for subsistence, generally in correspondence with coastal versus inland settlement location.

The Ceramic Age village of Sabazan sits on the Atlantic coast of Carriacou, an island $195 \mathrm{~km}$ north of Venezuela (Figure 1). Carriacou lies within the Grenadine Bank, a shallow, productive marine bank extending ca. $4000 \mathrm{~km}^{2}$ from Grenada through the Grenadines microarchipelago in the southernmost Lesser Antilles. The island is surrounded by mixed hard and soft bottom substrates, sand and seagrass beds, and extensive coral reefs, including some of the only barrier reefs in the southern Caribbean. The island's small area 
$\left(34 \mathrm{~km}^{2}\right)$ and low relief (maximum $291 \mathrm{~m}$ ) limit orographic rainfall. A lack of fresh surface water creates chronic water shortages for contemporary islanders and likely did so for Indigenous inhabitants in the past, as evidenced by the archaeological presence of ceramic pot-stack well heads for tapping underground water [38].

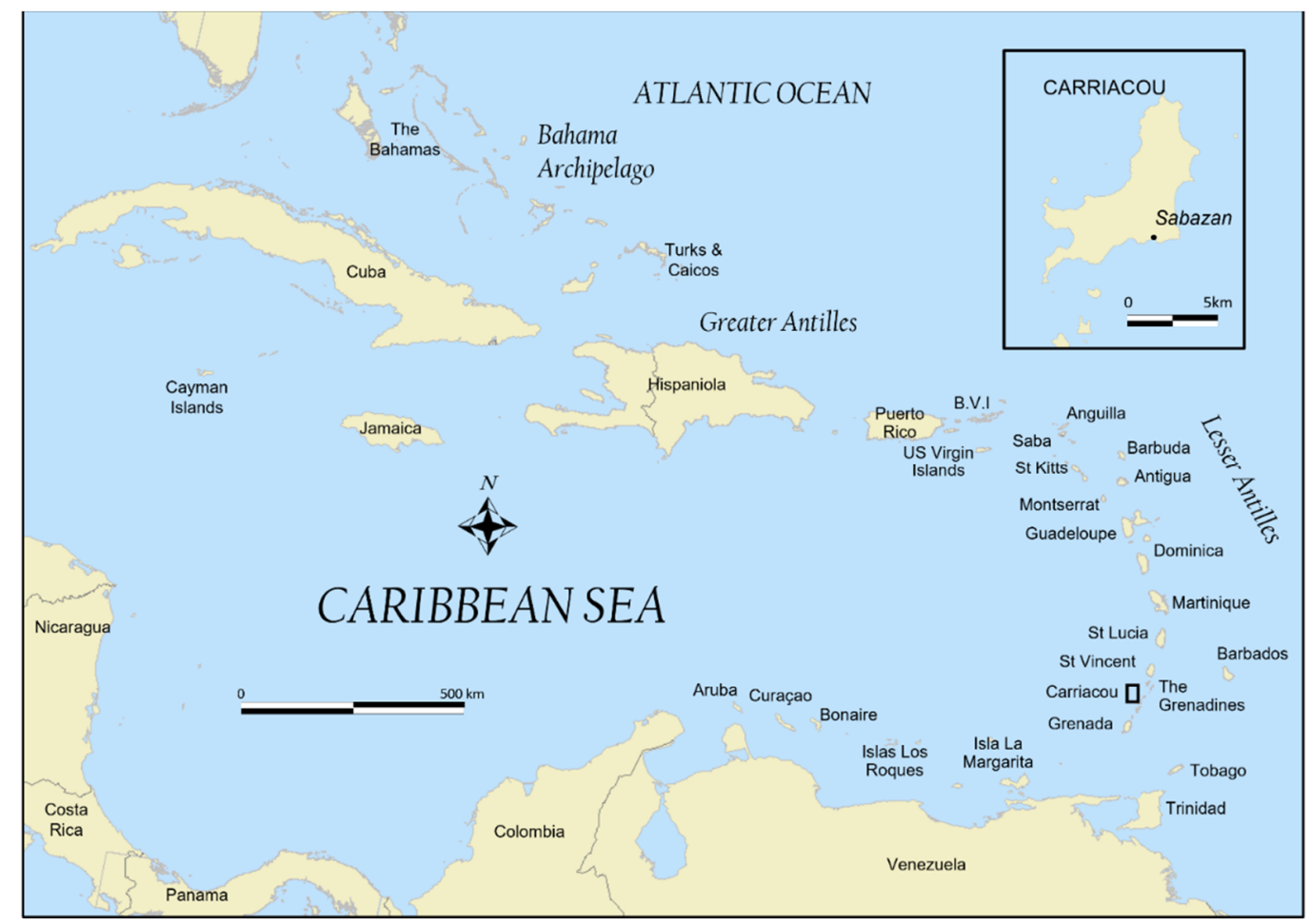

Figure 1. Map of the Caribbean showing the location of Carriacou and the Sabazan site.

Settled ca. AD 400, Sabazan, along with the nearby site of Grand Bay, is the oldest recorded site on Carriacou. More than two dozen radiocarbon dates indicate the site was occupied continuously until ca. AD 1400 [39]. Prior study of well-preserved zooarchaeological remains from stratified midden deposits (number of identified specimens $(\mathrm{NISP})=9660$; minimum number of individuals $(\mathrm{MNI})=837)$ showed Sabazan's inhabitants relied heavily on fish, especially parrotfish (Labridae: Scarinae), tunas (Thunnini), and jackfish and scads (Carangidae), as well as mollusks like the queen conch (Aliger gigas, formerly Strombus gigas), West Indian topsnail (Cittarium pica), and tessellated nerite (Nerita tessellata) $[39,40]$. Marine resources were supplemented by low numbers of terrestrial vertebrates (NISP $=830, \mathrm{MNI}=69$ ), consisting primarily of introduced South American mammals, such as the agouti (Dasyprocta sp.) and opossum (Didelphis sp.) [40,41]. Among the more noticeable trends at Sabazan is a pronounced, statistically significant reduction in fishing and concurrent increase in mollusk collection through time. Between AD 800 and 1400 , fish decrease from $35.6 \%$ of assemblage MNI to $20.5 \%$, while mollusks increase from $50.7 \%$ to $70.2 \%$, driven primarily by increases in gastropods, especially the small tessellated nerite. This shift from energetically more profitable fish to less "bang-for-buck" mollusks is consistent with foraging theory predictions for resource depression [39]. No decrease in the average size of tessellated nerites was associated with their increased exploitation [28].

\subsection{Forging Theory, Resource Depression, and Abundance Indices}

Explicit applications of foraging theory in the Caribbean are limited [28,29,39,42] due partly to an incongruous intellectual history and possibly a perceived reductionism of human behavioral complexity. Nonetheless, while ethnoarchaeological findings sometimes deviate from foraging theory predictions [42], numerous archaeological studies across a varied locales demonstrate the robustness of foraging theory models for assessing 
diachronic change in human resource exploitation and impacts on prey abundance in archeology [20,43-46]. Combined application of the prey choice and patch choice models, in particular, can permit hypotheses of anthropogenic decline in prey abundance, known as resource depression, to be developed and tested archaeologically. The two models follow from an assumed fitness-maximizing goal based in neo-Darwinian logic. The prey choice model presumes that higher-ranking prey will always be taken by foragers on encounter, with new prey incorporated into the diet in descending rank order when encounter rates with higher-ranking prey decline, a process termed diet breadth expansion $[45,47,48]$. Where resources are spatially clumped, the patch choice model and marginal value theorem predict that foragers will exploit a patch until the average return rate falls below that for the next-ranked patch and will incorporate additional patches sequentially into the diet until the point at which adding a lower ranked patch diminishes overall mean return, with travel time between patches included $[18,48]$. Prey and patch rankings are generally based on the rate of net energetic return per unit of time, although other currencies may be used.

Because archaeological demonstration of prey rank can be difficult, prey body size is frequently used as a proxy for rank, with larger prey ranking more highly up to the point where added size incurs disproportionate costs, as with whale hunting for example [44]. Although by no means a marginal resource of last resort [49-51], foraging theory models typically treat mollusks as low-ranking prey due to their relatively small size and high handling costs [52]. Their increase in the archaeological record relative to larger vertebrate resources is often heralded as an indicator of declining foraging efficiency and evidence for resource depression [32,53,54].

Following the prey and patch choice models, an abundance index (AI), which measures the relative assemblage contribution of high-ranked prey/patches to low-ranked prey/patches, can be used to measure the declining resource encounter rates and foraging efficiency that signal resource depression $[44,55,56]$. Since reduced encounter rates may be driven by factors other than resource depression, the significance of a single declining AI needs to be verified through other lines of evidence. Resource depression may be corroborated by diet breadth expansion or switching to less profitable prey and patches, declining mean age or body size of prey, foraging increasingly farther afield, and more intensive use of existing prey or patches [15,45,46,57]. As noted above, these effects have been demonstrated within archaeological fisheries [11,12,58-60] as a decrease in the average size and biomass of fish as people "fish through" [17,61] larger bodied taxa and turn increasingly to smaller species or pelagic fish farther offshore.

\section{Materials and Methods}

I used abundance indices incorporating body size and fish habitat to test the predictions of expanded diet breadth, declining prey body size, and shifts to more distant fishing patches described above. These indices are scaled between 0.0 and 1.0, with larger values indicating a greater proportion of high-ranking taxa in the assemblage. Zooarchaeological fish and gastropod data come from Middle (AD 750/800-1000), Late (ca. AD 1000-1200), and Final (ca. AD 1250-1400) occupation periods of Units 1 of Trenches (excavation blocks) 1 and 2 and a $50 \times 50 \mathrm{~cm}$ coastal profile column sample reported in Giovas [28,39]. Sample sizes from earlier deposits were too small to be included in statistical analysis. Deposits were trowel-excavated according to natural stratigraphic levels, subdivided into $10 \mathrm{~cm}$ arbitrary levels, and screened through nested 6.4 and $1.6 \mathrm{~mm}$ mesh. Arbitrary levels were aggregated by strata, which were assigned to temporal periods based on multiple ${ }^{14} \mathrm{C}$ dates on charcoal from each trench [39].

Fish and gastropod specimens were identified using modern reference collections at the Florida Museum of Natural History and Royal Ontario Museum, published identification guides [62,63], and the author's reference collection. Habitat designations follow Newsom and Wing [32], except that I explicitly included neritic (continental shelf) waters within the pelagic zone, and FishBase [64] (Supplemental Table S2). Taxa that could not be assigned to a habitat due to insufficient taxonomic resolution were excluded from analysis. 
Extended details of analytic protocols are discussed in [39]. I relied on body size as a proxy for return rates [19] rather than make assumptions about prey capture methods (e.g., use of mass capture techniques, foraging by children). This allows large fish to be ranked above small fish, and collective fish above collective gastropods. Queen conch is excluded from analysis because its large shell (up to $\sim 35 \mathrm{~cm}$ and $\sim 2 \mathrm{~kg}$ ) was handled differently from other taxa by Indigenous Caribbeans. Most conch shells were apparently discarded at the harvest location, with shells returned to the residential site subsequently modified heavily for artifact manufacture, precluding their dietary analysis [39].

The relationship between fish and gastropod abundance was evaluated using the fish index, which quantifies changes in the MNI of fish relative to that of gastropods, based on the dataset reported in Giovas [39], summarized for all classes in Table 1, and presented in detail in Supplementary Table S1.

$\mathrm{MNI}$ is a preferred quantifier in this instance because the disparity in the number of (exo)skeletal elements between fish (hundreds) and gastropod (one) inviduals inflates the relative contribution of fish to the assemblage when measured by NISP. The fish index is calculated in Equation (1):

$$
\text { Fish Index }=\frac{\sum \text { MNI fish }}{\sum(\text { MNI fish }+ \text { MNI gastropods })}
$$

Following from the assumption that foragers will preferentially target larger, higherranking fish over small, lower-ranking fish, I employ a large fish (LF) index to explore the potential for declining foraging efficiency within fishing. Small fish were defined as those with anterior vertebral widths under ca. $3 \mathrm{~mm}$ (irrespective of taxon) and represent fish for whom all skeletal elements (except a fused neurocranium) are captured by the 1.6 $\mathrm{mm}$ screen. Large fish were those lying above this size threshold. Original data appear in Giovas [39]. The index employs MNI values standardized per $10 \mathrm{~cm}^{3}$ to correct for larger volumetric analysis of the $6.4 \mathrm{~mm}$ screen fraction and is calculated in Equation (2):

$$
\text { Large Fish Index }=\frac{\sum \text { MNI large fish }}{\sum(\text { MNI large fish }+ \text { MNI small fish })}
$$

Finally, the large nearshore fish (LNSF) index groups coral reef and inshore fish into a single nearshore category and compares relative exploitation of large to small fish within this patch. Data are from Giovas [39]. The LNSF index also employs standardized MNIs and is calculated in Equation (3):

$$
\text { Large Nearshore Fish Index }=\frac{\sum \text { MNI large nearshore fish }}{\sum(\text { MNI large nearshore fish }+ \text { MNI small nearshore fish })}
$$

Statistics were calculated using Excel and R software. Chi-square tests were employed to evaluate abundance changes in overall gastropods and nerites (Nerita spp.), with $p$ values computed using a Monte Carlo approximation. A Cochran-Armitage test was used to test for a linear trend in the fish index. 


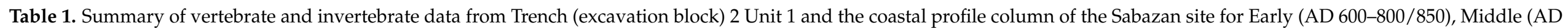
750/800-1000), Late (ca. AD 1000-1200), and Final (ca. AD 1250-1400) periods. See online Supplemental Table S1 for detailed data.

\begin{tabular}{|c|c|c|c|c|c|c|c|c|c|c|c|c|c|c|c|c|c|c|c|c|c|}
\hline \multirow[b]{2}{*}{ Taxon } & \multirow[b]{2}{*}{ Common Name } & \multicolumn{4}{|c|}{ Early Period } & \multicolumn{4}{|c|}{ Middle Period } & \multicolumn{4}{|c|}{ Late Period } & \multicolumn{4}{|c|}{ Final Period } & \multicolumn{4}{|c|}{ Site Total } \\
\hline & & NISP & $\begin{array}{c}\% \\
\text { NISP } \\
\end{array}$ & MNI & $\begin{array}{c}\% \\
\text { MNI }\end{array}$ & NISP & $\begin{array}{c}\% \\
\text { NISP }\end{array}$ & MNI & $\begin{array}{c}\% \\
\text { MNI }\end{array}$ & NISP & $\begin{array}{c}\% \\
\text { NISP }\end{array}$ & MNI & $\begin{array}{c}\% \\
\text { MNI }\end{array}$ & NISP & $\begin{array}{c}\% \\
\text { NISP }\end{array}$ & MNI & $\begin{array}{c}\% \\
\text { MNI }\end{array}$ & NISP & $\begin{array}{c}\% \\
\text { NISP }\end{array}$ & MNI & $\begin{array}{c}\% \\
\text { MNI }\end{array}$ \\
\hline Actinopterygii & $\begin{array}{l}\text { bony ray-finned } \\
\text { fishes }\end{array}$ & 30 & 14.2 & 10 & 30.3 & 668 & 29.0 & 106 & 35.6 & 151 & 14.7 & 31 & 30.7 & 156 & 11.5 & 33 & 20.6 & 1005 & 20.5 & 180 & 30.4 \\
\hline Aves & birds & & & & & 3 & 0.1 & 2 & 0.7 & & & & & 1 & 0.1 & 1 & 0.6 & 4 & 0.1 & 3 & 0.5 \\
\hline Mammalia & mammals & 16 & 7.6 & 4 & 12.1 & 90 & 3.9 & 12 & 4.0 & 9 & 0.9 & 3 & 3.0 & 9 & 0.7 & 2 & 1.3 & 124 & 2.5 & 21 & 3.5 \\
\hline Reptilia & reptiles & 4 & 1.9 & 2 & 6.1 & 55 & 2.4 & 6 & 2.0 & 16 & 1.6 & 3 & 3.0 & 52 & 3.8 & 2 & 1.3 & 127 & 2.6 & 13 & 2.2 \\
\hline Echinoidea & sea urchins & 13 & 6.2 & 1 & 3.0 & 329 & 14.3 & 8 & 2.7 & 332 & 32.3 & 5 & 5.0 & 596 & 44.1 & 6 & 3.8 & 1270 & 26.0 & 20 & 3.4 \\
\hline Bivalvia & clams, oysters & 1 & 0.5 & 1 & 3.0 & 68 & 3.0 & 20 & 6.7 & 7 & 0.7 & 3 & 3.0 & 18 & 1.3 & 8 & 5.0 & 94 & 1.9 & 32 & 5.4 \\
\hline Gastropoda & sea and land snails & 124 & 58.8 & 12 & 36.4 & 334 & 14.5 & 111 & 37.2 & 159 & 15.5 & 46 & 45.5 & 262 & 19.4 & 92 & 57.5 & 879 & 18.0 & 261 & 44.1 \\
\hline Polyplacophora & chitons & 4 & 1.9 & 2 & 6.1 & 140 & 6.1 & 20 & 6.7 & 44 & 4.3 & 8 & 7.9 & 112 & 8.3 & 13 & 8.1 & 300 & 6.1 & 43 & 7.3 \\
\hline Decapoda & crabs & 19 & 9.0 & 1 & 3.0 & 614 & 26.7 & 12 & 4.0 & 309 & 30.1 & 2 & 2.0 & 147 & 10.9 & 3 & 1.9 & 1089 & 22.3 & 18 & 3.0 \\
\hline Cirripedia & barnacles & & & & & 1 & 0.0 & 1 & 0.3 & & & & & & & & & 1 & 0.0 & 1 & 0.2 \\
\hline Total & & 211 & & 33 & & 2302 & & 298 & & 1027 & & 101 & & 1353 & & 160 & & 4893 & & 592 & \\
\hline
\end{tabular}




\section{Results}

The fish index declined across the Middle (0.486), Late (0.403), and Final periods (0.264) of occupation at Sabazan, with the temporal reduction in fish relative abundance registering as significant according to a Cochran-Armitage test $(p<0.001)$ (Figure 2, Table 2).

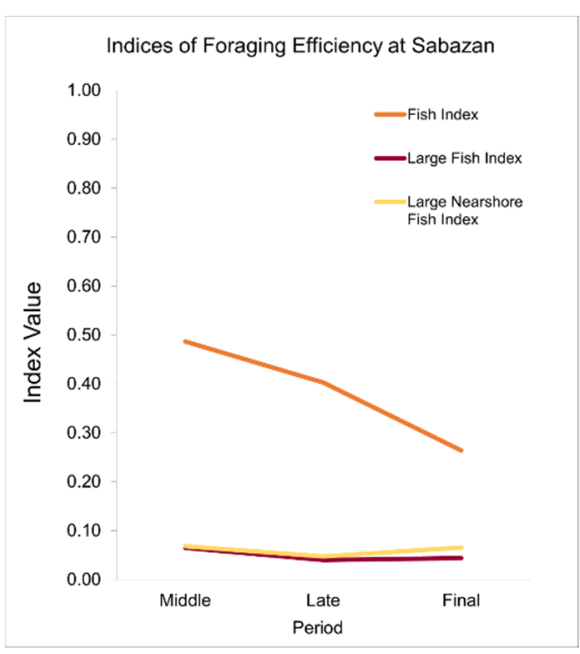

Figure 2. Comparisons of the fish index, large fish index, and large nearshore fish index across Middle (AD 750/800-1000), Late (ca. AD 1000-1200), and Final (ca. AD 1250-1400) periods at Sabazan.

Table 2. Fish index variation over Middle, Late, and Final periods at Sabazan, and results of the Cochrane-Armitage test for linear trends.

\begin{tabular}{|c|c|c|c|c|}
\hline \multicolumn{5}{|c|}{ Sabazan Fish Index } \\
\hline & Fish MNI & Gastropod MNI & $\begin{array}{l}\text { Total Fish and } \\
\text { Gastropod MNI }\end{array}$ & Fish Index \\
\hline Final & 33 & 92 & 125 & 0.264 \\
\hline Late & 31 & 46 & 77 & 0.403 \\
\hline Middle & 106 & 112 & 218 & 0.486 \\
\hline Total & 170 & 250 & 420 & \\
\hline Cochran-Armitage Test & & $p$ & & \\
\hline$x^{2}:$ & 16.29 & $<0.001$ & & \\
\hline$\chi^{2}{ }_{\text {trend }}:$ & 16.09 & $<0.001$ & & \\
\hline Departure from linearity: $\chi^{2}$ : & 0.19 & 0.659 & & \\
\hline
\end{tabular}

The LF index exhibits only a marginal decline over the three periods (Middle: 0.065; Late: 0.040; Final: 0.044), reflecting a nominal decrease in large fish of roughly $2 \%$ over 600 years (Figure 2, Table 3). Similarly, the LNSF showed only minor fluctuations of about $2 \%$, with values for the Final period (0.068) slightly higher than those of the Late period (0.047) and almost equal to the Middle period (0.068) (Table 4). Both gastropod and nerite abundance increased significantly from the Middle to the Final occupation periods (Gastropoda: $\chi^{2}=21.69, p=0.004$, Gastropoda adjusted residual $=4.066, p<0.001$; Neritidae: $\chi^{2}=68.72, p=0.004$, Nerita spp. adjusted residual $=5.173, p<0.001$ ). 
Table 3. Large fish index variation over Middle, Late, and Final periods at Sabazan.

\begin{tabular}{cccccc}
\hline \multicolumn{5}{c}{ Sabazan Large Fish Index } \\
\hline Period & Large Fish MN & $\begin{array}{c}\text { * Stndrd. Large Fish } \\
\text { MNI }\end{array}$ & Small Fish MNI & $\begin{array}{c}\text { * Stndrd. Small Fish } \\
\text { MNI }\end{array}$ & Large Fish Index \\
\hline Final & 17 & 0.39 & 32 & 8.51 & 0.044 \\
Late & 10 & 0.20 & 25 & 4.78 & 0.040 \\
Middle & 49 & 0.26 & 106 & 3.72 & 0.065 \\
Total & 76 & & 163 & \\
\hline
\end{tabular}

* Standardized per $10 \mathrm{~cm}^{3}$.

Table 4. Large nearshore fish index variation over Middle, Late, and Final periods at Sabazan.

\begin{tabular}{cccccc}
\hline Sabazan Large Nearshore Fish Index & & \\
\hline Period & $\begin{array}{c}\text { Large Nearshore } \\
\text { Fish MNI }\end{array}$ & $\begin{array}{c}\text { * Stndrd. Large } \\
\text { Nearshore Fish } \\
\text { MNI }\end{array}$ & $\begin{array}{c}\text { Small Nearshore } \\
\text { Fish MNI }\end{array}$ & $\begin{array}{c}\text { *Stndrd. Small } \\
\text { Nearshore Fish } \\
\text { MNI }\end{array}$ & $\begin{array}{c}\text { Large Nearshore } \\
\text { Fish Index }\end{array}$ \\
\hline Final & 13 & 0.30 & 16 & 4.25 & 0.065 \\
Late & 8 & 0.16 & 17 & 3.25 & 0.047 \\
Middle & 38 & 0.20 & 78 & 2.74 & 0.068 \\
Total & 59 & & 111 & & \\
\hline
\end{tabular}

* Standardized per $10 \mathrm{~cm}^{3}$.

As an addendum to the LNSF results, it should be noted that some herring (Clupeidae) species live closer to shore than others. The clupeid specimens in this study were treated as offshore taxa (Supplemental Table S2), but because they were not identifiable to a lower taxon, the possibility exists that some or all of these may have been nearshore fish. To test whether this possibility impacts results, I calculated the large nearshore fish index with clupeids designated as nearshore taxa. Recalculated LNSF indices are: Middle period $=0.065$, Late period $=0.042$, and Final period $=0.053$. These results leave the conclusions, discussed below, unchanged.

\section{Discussion}

The diachronic decline in the fish index points to a switch from higher ranking fish to lower ranking gastropods and an overall reduction in foraging efficiency at Sabazan, consistent with resource depression patterning. Whether this trend for diminished fishing is in fact due to changes in energetic returns from the fish catch remains in question, however. By testing how the size of archaeological fish changes over time, as noted above, the LF index provides a measure of foraging efficiency for assessing this question. A decline would be expected if, as large fish became depleted, Sabazan's residents exploited progressively lower ranking fish before finally turning to gastropods. However, the LF index exhibits only a marginal decrease from the Middle to Final periods (Figure 2, Table 3). The comparative stability of large fish's relative abundance, illustrated by the nearly flat line of the LF index in Figure 2, against the backdrop of sharply reduced fishing signaled by the fish index thus suggests the latter trend is not driven by declining energetic returns for large fish. These results are supported by a separate study that showed no change over time in the mean size of tunas (Thunnini) [65], one of the most heavily exploited fish taxa at Sabazan (Supplemental Table S1).

Prior statistical tests of the Sabazan assemblage showed no change over time in the use of more distant offshore pelagic patches compared to coral reef and inshore patches [28,39], in contrast to trends observed for resource depression scenarios elsewhere in the pre-contact Caribbean [12,32]. Stable pelagic fish exploitation could nonetheless be consistent with resource depression if Sabazan's residents had chosen to increase exploitation of intertidal and shallow water invertebrates in lieu of pursuing potentially riskier or less efficient 
offshore fish. Accordingly, nearshore fish assemblages should exhibit evidence for foraging efficiency declines in the form of increased incorporation of smaller fish into the diet as encounter rates with larger nearshore fish decline. This should occur before or with the gastropod increase observed through the Middle to Final occupation periods, which is driven largely by mounting nerite exploitation $[39,40]$. The LNSF index values reveal that a shift to smaller inshore fish did not occur. As with the LF index, foraging efficiency appears relatively stable, and the index trendline is nearly flat (Figure 2).

In sum, the application of fish abundance indices that incorporate theoretical expectations for diet breadth expansion, changing prey size, and shifts in patch exploitation do not support the occurrence of resource depression at Sabazan between AD 800-1400. These findings align with previous studies showing no evidence for resource depression in tunas and tessellated nerites at Sabazan based on size frequency data [28,65]. In this sense, fishing at Sabazan appears to have been sustainable. The resilience of the fishery may have been due to the relative ecological richness of the surrounding Grenadine Bank, but additional study is needed to rule out alternative causes for the observed patterning, such as agricultural intensification that may have offset fishing pressure.

It is possible that data resolution or other analytic factors are masking overfishing at Sabazan. The large and small size classes used in this study, for instance, may be too coarse-grained to capture variation over time. Additional investigations based on allometric reconstructions of fish size or biomass may offer further insights by providing higher resolution data $[9,30]$.

It may also be the case that fish size is a poor proxy for return rate. Mass capture technology, such as nets and basket traps, can increase foraging return-rates by increasing gross energetic return and/or lowering pursuit and handling costs [46]. Small fish caught with nets at Sabazan may have been comparable in their energetic return rate to large fish caught by hook and line or other techniques, which would imply that the LF and LNSF indices do not measure foraging efficiency as intended. This seems unlikely, however, for three reasons. First, nets catch fish above a certain size threshold dictated by the net gauge, including larger fish. Thus, the expectation remains that as fishing pressure mounts and fish larger than this size threshold are removed from the population, people will employ increasingly finer-gauge nets, thereby adding smaller fish to the diet. Second, capture technique is not predicated solely on fish size but also behavior and anatomy. For example, parrotfish, which are among the most common fish at Sabazan (Supplemental Table S1), are not amenable to hook and line fishing due to their beak-like mouth structure. Across a range of sizes, they were likely caught primarily with traps and nets $[9,66]$. Body size within this taxon should therefore generally track energetic return rates. Finally, studies in the Caribbean empirically demonstrate mean size declines in multiple fish taxa in association with other indicators of overfishing, such as trophic level [11,12]. Thus, there are strong reasons to believe that the apparent absence of resource depression at the Sabazan site is a genuine phenomenon.

It is still the case that overall fish relative abundance declines over time at Sabazan, however, and there is no immediate explanation for this. The change correlates roughly with increasing aridity documented between 1200-800 cal. BP in sediment cores from Lake Antoine on nearby Grenada [67], possibly reflecting the effects of the Medieval Warm Period (MWP), ca. AD 950-1250. Circum-Caribbean paleoclimate records for the MWP indicate warmer sea surface temperatures (SST) and potential increased frequency of hurricanes and major storms [68-70] that may have negatively affected Carriacou's reef system. These changes may have altered fish abundance by negatively impacting food availability and habitat. Climate warming in the modern era is associated with pronounced ENSO events in the Pacific (although these may have been less frequent during the MWP) [71], warmer SSTs, and increased tropical cyclone strength and frequency that contribute to significant coral bleaching episodes and reef die-off in the Caribbean [72-75]. Temperatures in the Caribbean during the MWP would have been similar to or slightly warmer than today. The impacts of modern climate warming on reefs, however, are exacerbated by the effects 
of eutrophication, commercial fishing, and coastal development, which would have been moot a millennium ago. Further research is thus needed to determine whether climate effects played a role in Sabazan's fishing declines.

Sabazan is not unique in its lack of evidence for fish and gastropod overexploitation. At five sites on Anguilla dated to the Late Ceramic Age (AD 500-1500), analyses of archaeological fish abundance-biomass curves, trophic structure, fish size, and taxonomic composition show sustainable long-term exploitation of a "healthy fishery" [26]. At Roseau on Basse-Terre, Gaudeloupe, Bochaton et al. [25] found no change over time in the mean trophic level of fish between ca. AD 1000-1400, nor was there any change in the size distribution of Sparisoma parrotfish. Similarly, Grouard [76] detected no evidence for overfishing based on fish standard length distributions at Anse à la Gourde (ca. AD 400-1400), on Grande-Terre, Guadeloupe. In a related phenomenon, at the Coconut Walk site, Nevis, tessellated nerites increased in mean length between AD 890 and AD 1440, concurrent with pronounced increases in their exploitation [29]. The continued availability of tessellated nerites coupled with size increase suggest that human predation pressure may have enhanced growth rates by reducing population density, but harvest levels overall were sustainable.

These collective findings underscore the heterogeneous trajectories of Indigenous social-ecological systems in the Caribbean. Because they represent instances where researchers specifically sought to examine zooarchaeological assemblages for anthropogenic impacts, it may be that negative evidence for overfishing is more widespread but has been missed due to a lack of testing. While it is difficult to know how ubiquitous sustainable exploitation was across the region, these results highlight the coexistence of both ecologically sustainable and unsustainable practices during the pre-contact era and the dynamism of Indigenous-environmental interactions. Considering Caribbean cultural and environmental diversity in the pre-contact era, it is foreseeable that different locations would have experienced variable social-ecological outcomes based on local, historically contingent circumstances, including the nature of geophysical and hydrological variables, biotic communities, marine habitat structure, human population density, cultural traditions, resource exploitation and management strategies, and available technology. Nonetheless, speculation about the extent to which locally observed sustainability or unsustainability characterizes the wider pre-contact Caribbean is premature. Instead, there is a real need to evaluate this issue at the archipelagic level through meta-analyses integrating regional datasets, following the recent example of Grouard et al. [9] for the northern Lesser Antilles and of archaeologists in regions beyond the Caribbean [77,78].

There are additional issues entangled in the Caribbean fisheries studies discussed above that warrant deeper consideration as archaeologists continue to explore human effects on island ecosystems. Previous studies (including those conducted by myself and colleagues, e.g., [28,29]) have employed the term "sustainable" in evaluations of anthropogenic impacts based on fish and mollusk abundance indices, size, trophic level, prey and patch switching, and other measures. In these studies, the term is often used without precision to connote the long-term viability of human exploitation strategies. Across the Caribbean literature, "sustainability" is either undefined, loosely defined, or directly benchmarked against different zooarchaeological and/or modern-fisheries criteria, a situation which appears to characterize archaeological fisheries studies in general [1,7,79]. In practice, then, the term acts as a boundary concept rather than referencing a specific ecological state defined by scientific consensus. This is not necessarily inappropriate. Boundary concepts are powerful precisely because their fuzzy parameters allow them to transcend disciplines and unify diverse communities for action [80]. However, it does raise fundamental questions. What is meant by sustainability? How do we compare findings for ancient sustainable practices across contexts where different standards have been used? And, are some methodologies more valid than others for demonstrating sustainability in the deeper past given the issues of data scale and resolution involved? In the present study and others, there is an implied assumption that a lack of evidence for resource 
depression amounts to sustainable resource use. Is it valid to rely on negative evidence in this way? Should we instead employ the presence of certain indicators of sustainability, perhaps drawing on quantitative criteria from fisheries science $[7,26]$ ?

Marshall and Levin [81] highlight the problematic nature of the sustainability concept for modern fisheries. Here, sustainability is often framed in terms of the maximum sustainable yield (MSY), determined through complex single-species assessment models in which harvest rates are set to maximize the catch but not exceed the maximum population growth rate $[82,83]$. These models seek to optimize fish harvest for economic purposes while in theory, if not in practice, allowing stocks to replenish [82]. According to Marshall and Levin [81], the MSY and additional, looser constructs fall short of securing true sustainability because they fail to consider other ecological and social goals, such as species interactions, the ecosystem services provided by target taxa, or the distribution of and equitable access to marine resources by all stakeholders. Applying these considerations to ancient fisheries presents a challenge: even if quantitative sustainability criteria informed by modern fisheries science are satisfied, can we know that other social and ecological dimensions of sustainability were also achieved in the past?

This is more than an academic point. Archaeological data have greater applied value to contemporary conservation and restoration ecology when they can rigorously demonstrate the social-ecological conditions that fostered past sustainability, who benefitted from this, and how. Past sustainability based largely in low human population densities or modest predation pressure-which Baisre [8] contends characterize the Caribbeanmay be of limited relevance in modern conservation because these conditions cannot be feasibly replicated across significant areas of the modern world, although the archaeological assemblages demonstrating sustainability may still be a valuable source of baseline data $[1,7,26,84]$.

This critique is relevant to aspects of the evidence for sustainable fisheries identified at Sabazan. If sustainable systems are characterized by resilience, meaning they have the capacity to endure over extended periods without undermining their preconditions [85], then tessellated nerite sustainability at Sabazan and also at Coconut Walk, Nevis, may be regarded as precarious. At both locations, most harvested snails fall below the minimum size at onset of reproductive maturity $(14-17 \mathrm{~mm}$ ) [86]. Continued exploitation was thus dependent on outside veliger recruitment to sustain local populations. As such, it would have been vulnerable to any future effects undermining this potential, including changes in bay circulation, foraging intensification that outstripped recruitment, or resource depression in the wider nerite populations providing a rescue effect. How long this precarious sustainability may have endured beyond ca. AD 1400 is thus open to question.

\section{Conclusions}

This study employed large fish and large nearshore fish abundance indices to test for the archaeological correlates of resource depression predicted by foraging theory and empirical studies in a 600-year record of fishing at the Sabazan site on Carriacou. Results contradict the scenario of overfishing suggested by a shift to intensified gastropod collection between ca. AD 800-1400 at Sabazan. There is no evidence for resource depression, and marine foraging can be considered sustainable in the sense that human exploitation of fish (and the tessellated nerite) does not appear to have affected the capacity of these taxa to persist through time.

These findings contribute to a growing body of evidence for sustainable resource use by Indigenous Caribbean peoples. In defiance of evidence for overfishing from other islands in the region, these cases of sustainability demonstrate the heterogeneous trajectories of social-ecological systems in the pre-contact Caribbean. Archaeologists need to acknowledge this diversity and leverage it to better understand the specific cultural and ecological conditions which foster sustainability over extended timescales. Meta-analyses integrating large, regional or inter-regional datasets will advance this effort. This endeavor should also include thoughtful evaluation of how the sustainability concept is applied to 
the archaeological fisheries record. Differing standards and metrics for sustainability mean that not all demonstrated "sustainabilities" are equal. A more critical, explicit approach to the definition and measurement of sustainability in ancient fisheries is recommended to resolve this issue. Ultimately, the value of these demonstrations to contemporary conservation and fisheries management rests on the ability of archaeologists to provide rigorous data with the potential for practical application.

There is an undeniable, urgent need for sustainable fisheries solutions for the modern Caribbean, which is considered among the most overfished regions in the world [87]. Caribbean fisheries production fell $40 \%$ between the mid-1990s and mid-2010s, with $55 \%$ of commercial stocks registering as overfished or depleted [87]. The impact of overexploitation on marine ecology has been exacerbated by pollution, eutrophication, coastal development, the Diadema antillarum urchin die-off of the 1980s, mass coral mortality due to White Band Disease and bleaching events induced by warming oceans, and more recently, "brown tide" Sargassum algal blooms and the Red Lionfish (Pterois volitans) invasion [88-91]. The average cover of coral reefs, which are integral to supporting fisheries and the food security and livelihood of Caribbean coastal communities [92], has been more than halved in the last five decades (from 34.8\% to 16.3\% between 1970 and 2012) [89]. Archaeological and historical data offer the ability to chart long-term change in marine environments and the effects of (over-)fishing in the absence of the above-noted synergistic factors, which characterize only the last century in five millennia of human-marine entanglements. Knowledge of the comparative sustainability of Indigenous fishing across the region, in particular, may reveal important baselines and even the early genesis of the fisheries depletion that characterizes the Caribbean today.

Supplementary Materials: The following are available online at https:/ /www.mdpi.com/article/10 $.3390 /$ su13169152/s1. Supplemental Table S1. Zoorchaeological remains recovered from the Sabazan site. Supplemental Table S2. Habitat assignments for archaeological fish taxa identified at Sabazan.

Funding: A portion of this research was funded by grants from the National Science Foundation (grant no. SBE-0715388), the University of Washington Quaternary Research Center, and the University of Washington Department of Anthropology.

Institutional Review Board Statement: Not applicable.

Informed Consent Statement: Not applicable.

Data Availability Statement: The original data on which this study is based is available in Giovas [39].

Acknowledgments: I thank Jon Erlandson, Scott M. Fitzpatrick and Michelle LeFebvre for the invitation to contribute to this special issue, the editors and anonymous reviewers for their constructive suggestions that improved the final version of my paper, and the Carriacou Historical Society for their support, generosity, and collaboration.

Conflicts of Interest: The author declares no conflict of interest.

\section{References}

1. Barrett, J.H. An environmental (pre) history of European fishing: Past and future archaeological contributions to sustainable fisheries. J. Fish Biol. 2019, 94, 1033-1044. [CrossRef] [PubMed]

2. Braje, T.J.; Rick, T.C.; Szpak, P.; Newsome, S.D.; McCain, J.M.; Smith, E.A.; Glassow, M.; Hamilton, S.L. Historical ecology and the conservation of large, hermaphroditic fishes in Pacific Coast kelp forest ecosystems. Sci. Adv. 2017, 3, e1601759. [CrossRef] [PubMed]

3. Cramer, K.L.; Jackson, J.B.; Donovan, M.K.; Greenstein, B.J.; Korpanty, C.A.; Cook, G.M.; Pandolfi, J.M. Widespread loss of Caribbean acroporid corals was underway before coral bleaching and disease outbreaks. Sci. Adv. 2020, 6, eaax9395. [CrossRef] [PubMed]

4. Cramer, K.L.; O'Dea, A.; Leonard-Pingel, J.S.; Norris, R.D. Millennial-scale change in the structure of a Caribbean reef ecosystem and the role of human and natural disturbance. Ecography 2020, 43, 283-293. [CrossRef]

5. Jackson, J.B.; Kirby, M.X.; Berger, W.H.; Bjorndal, K.A.; Botsford, L.W.; Bourque, B.J.; Bradbury, R.H.; Cooke, R.; Erlandson, J.; Estes, J.A.; et al. Historical overfishing and the recent collapse of coastal ecosystems. Science 2001, 293, 629-637. [CrossRef]

6. Pauly, D. Beyond duplicity and ignorance in global fisheries. WIT Trans. Eng. Sci. 2013, 64, 519-535. 
7. Plank, M.J.; Allen, M.S.; Nims, R.; Ladefoged, T.N. Inferring fishing intensity from contemporary and archaeological sizefrequency data. J. Archaeol. Sci. 2018, 93, 42-53. [CrossRef]

8. Baisre, J.A. Setting a baseline for Caribbean fisheries. J. Isl. Coast. Archaeol. 2010, 5, 120-147. [CrossRef]

9. Grouard, S.; Perdikaris, S.; Espindola Rodrigues, N.E.; Quitmyer, I.R. Size estimation of pre-Columbian Caribbean fish. Int. J. Osteoarchaeol. 2019, 29, 452-468. [CrossRef]

10. Stager, J.C.; Chen., V. Fossil evidence of shell length decline in queen conch (Strombus gigas L.) at Middleton Cay, Turks and Caicos Islands, British West Indies. Caribb. J. Sci. 1996, 32, 14-20.

11. Wing, E.S. The sustainability of resources used by Native Americans on four Caribbean islands. Int. J. Osteoarchaeol. 2001, 11, 14-23. [CrossRef]

12. Wing, E.S.; Wing, S.R. Prehistoric fisheries in the Caribbean. Coral Reefs 2001, 20, 1-8.

13. Butler, V.L. Seeking balance in "human impacts" research. Comment on Julio Baisre's "Setting a baseline for Caribbean fisheries". J. Isl. Coast. Archaeol. 2010, 5, 148-151. [CrossRef]

14. Reitz, E.J.; Quitmyer, I.R.; Marrinan, R.A. What are we measuring in the zooarchaeological record of prehispanic fishing strategies in the Georgia Bight, USA? J. Isl. Coast. Archaeol. 2009, 4, 2-36. [CrossRef]

15. Fenberg, P.B.; Roy, K. Ecological and evolutionary consequences of size-selective harvesting: How much do we know? Mol. Ecol. 2008, 17, 209-220. [CrossRef]

16. Jørgensen, C.; Enberg, K.; Dunlop, E.S.; Arlinghaus, R.; Boukal, B.S.; Brander, K.; Ernande, K.; Gårdmark, A.; Johnston, F.; Matsumura, S.; et al. Managing evolving fish stocks. Science 2007, 318, 1247-1248. [CrossRef]

17. Pauly, D.; Christensen, V.; Dalsgaard, J.; Froese, R.; Torres, F., Jr. Fishing down marine food webs. Science 1998, $279,860-863$. [CrossRef]

18. Charnov, E.L.; Orians, G.H.; Hyatt, K. Ecological implications of resource depression. Am. Nat. 1976, 110, 247-259. [CrossRef]

19. Broughton, J.M.; Cannon, M.D.; Bayham, F.E.; Byers, D.A. Prey body size and ranking in zooarchaeology: Theory, empirical evidence, and applications from the northern Great Basin. Am. Antiq. 2011, 76, 403-428. [CrossRef]

20. Byers, D.A.; Broughton, J.M. Holocene environmental change, artiodactyl abundances, and human hunting strategies in the Great Basin. Am. Antiq. 2004, 69, 235-255. [CrossRef]

21. Codding, B.F.; Bird, D.W.; Bird, R.B. Interpreting abundance indices: Some zooarchaeological implications of Martu foraging. J. Archaeol. Sci. 2010, 37, 3200-3210. [CrossRef]

22. Denevan, W.M. The pristine myth: The landscape of the Americas in 1492. Ann. Am. Assoc. Geogr. 1992, 82, 369-385. [CrossRef]

23. Curet, L.A. The archaeological perspective: Comment on Julio Baisre's "Setting a baseline for Caribbean fisheries. " J. Isl. Coast. Archaeol. 2010, 5, 152-155. [CrossRef]

24. McClenachan, L.; Hardt, M.; Jackson, J.; Cooke, R. Mounting evidence for historical overfishing and long-term degradation of Caribbean marine ecosystems: Comment on Julio Baisre's "Setting a baseline for Caribbean Fisheries". J. Isl. Coast. Archaeol. 2010, 5, 165-169. [CrossRef]

25. Bochaton, C.; Ephrem, B.; Bérard, B.; Cochard, D.; Gala, M.; Richter, K.K.; Le Lay, A.; Renou, S.; Lenoble, A. The pre-Columbian site of Roseau (Guadeloupe, FWI): Intra-site chronological variability of the subsistence strategies in a Late Ceramic archeological vertebrate assemblage. Archaeol. Anthropol. Sci. 2021, 13, 16. [CrossRef]

26. Carder, N.; Crock, J.G. A pre-Columbian fisheries baseline from the Caribbean. J. Archaeol. Sci. 2012, 39, 3115-3124. [CrossRef]

27. Carder, N.; Reitz, E.J.; Crock, J.G. Fish communities and populations during the post-Saladoid period (AD 600/800-1500), Anguilla, Lesser Antilles. J. Archaeol. Sci. 2007, 34, 588-599. [CrossRef]

28. Giovas, C.M. Though she be but little: Resource resilience, Amerindian foraging, and long-term adaptive strategies in the Grenadines, West Indies. J. Isl. Coast. Archaeol. 2016, 11, 238-263. [CrossRef]

29. Giovas, C.M.; Clark, M.; Fitzpatrick, S.M.; Stone, J. Intensifying collection and size increase of the tessellated nerite snail (Nerita tessellata) at the Coconut Walk site, Nevis, northern Lesser Antilles, AD 890-1440. J. Archaeol. Sci. 2013, 40, 4024-4038. [CrossRef]

30. LeFebvre, M.J. Zooarchaeological analysis of prehistoric vertebrate exploitation at the Grand Bay Site, Carriacou, West Indies. Coral Reefs 2007, 26, 931-944. [CrossRef]

31. Krigbaum, J.; Fitzpatrick, S.M.; Bankaitis, J. Human paleodiet at Grand Bay, Carriacou, Lesser Antilles. J. Isl. Coast. Archaeol. 2013, 8, 210-227. [CrossRef]

32. Newsom, L.A.; Wing, E.S. On Land and Sea: Native American Uses of Biological Resources in the West Indies; University of Alabama Press: Tuscaloosa, AL, USA, 2004.

33. Stokes, A.V. A Biogeographic Survey of Prehistoric Human Diet in the West Indies Using Stable Isotopes. Ph.D. Dissertation, University of Florida, Gainesville, FL, USA, 1998.

34. Keegan, W.F.; Hofman, C.L. The Caribbean Before Columbus; Oxford University Press: Oxford, UK, 2017.

35. Fitzpatrick, S.M. Verification of an Archaic age occupation on Barbados, southern Lesser Antilles. Radiocarbon 2011, 53, 595-604. [CrossRef]

36. Chinique de Armas, Y.; Buhay, W.M.; Suárez, R.R.; Bestel, S.; Smith, D.; Mowat, S.D.; Roksandic, M. Starch analysis and isotopic evidence of consumption of cultigens among fisher-gatherers in Cuba: The archaeological site of Canímar Abajo, Matanzas. J. Archaeol. Sci. 2015, 58, 121-132. [CrossRef]

37. Hofman, C.L.; Hoogland, M.L. Plum Piece: Evidence for archaic seasonal occupation on Saba, northern lesser Antilles around 3300 BP. J. Caribb. Archaeol. 2003, 4, 12-27. 
38. Schultz, C. The Carriacou Hypothesis: Bottomless stacked pots, a study in Amerindian fresh water procurement. In Proceedings of the XVI International Congress for Caribbean Archaeology; International Association for Caribbean Archaeology: Basse Terre, Guadeloupe, 1995; pp. 217-228.

39. Giovas, C.M. Foraging Variability in the Prehistoric Caribbean: Multiple Foraging Optima, Resource Use, and Anthropogenic Impacts on Carriacou, Grenada. Ph.D. Thesis, University of Washington, Seattle, WA, USA, 2013.

40. Giovas, C.M. Pre-Columbian Amerindian lifeways at the Sabazan site, Carriacou, West Indies. J. Isl. Coast. Archaeol. 2018, 13, 161-190. [CrossRef]

41. Rabinow, S.; Giovas, C.M. A systematic review of agouti (Dasyproctidae: Dasyprocta) records from the pre-1492 Lesser Antilles: New perspectives on an introduced commensal. Int. J. Osteoarchaeol. 2021. [CrossRef]

42. Keegan, W.F. The People Who Discovered Columbus: The Prehistory of the Bahamas; University of Florida Press: Gainesville, FL, USA, 1992.

43. Jones, S. A Long-term perspective on biodiversity and marine resource exploitation in Fiji's Lau Group. Pac. Sci. 2009, 63, 617-648. [CrossRef]

44. Broughton, J.M. Widening diet breadth, declining foraging efficiency, and prehistoric harvest pressure: Ichthyofaunal evidence from the Emeryville Shellmound, California. Antiquity 1997, 71, 845-862. [CrossRef]

45. Lupo, K.D. Evolutionary foraging models in zooarchaeological analysis: Recent applications and future challenges. J. Archaeol. Res. 2007, 15, 143-189. [CrossRef]

46. Nagaoka, L. Declining foraging efficiency and moa carcass exploitation in southern New Zealand. J. Archaeol. Sci. 2005, 32, 1328-1338. [CrossRef]

47. Kaplan, H.; Hill, K. The evolutionary ecology of food acquisition. In Evolutionary Ecology and Human Behavior; Smith, E.A., Winterhalder, B., Eds.; Aldine de Gruyter: New York, NY, USA, 1992; pp. 167-201.

48. Stephens, D.W.; Krebs, J.R. Foraging Theory; Princeton University Press: Princeton, NJ, USA, 1986.

49. Claassen, C. Shells; Cambridge University Press: Cambridge, UK, 1998.

50. Erlandson, J.M. The role of shellfish in prehistoric economies: A protein perspective. Am. Antiq. 1988, 53, 102-109. [CrossRef]

51. Erlandson, J.M. The archaeology of aquatic adaptations: Paradigms for a new millennium. J. Archaeol. Res. 2001, 9, 287-350. [CrossRef]

52. Ugan, A. Does size matter? Body size, mass collecting, and their implications for understanding prehistoric foraging behavior. Am. Antiq. 2005, 70, 75-89. [CrossRef]

53. Blick, J. Pre-Columbian impact on terrestrial, intertidal, and marine resources, San Salvador, Bahamas (A.D. 950-1500). J. Nat. Conserv. 2007, 15, 174-183. [CrossRef]

54. Erlandson, J.M.; Rick, T.C.; Braje, T.J. Fishing up the food web?: 12,000 years of maritime subsistence and adaptive adjustments on California's Channel Islands. Pac. Sci. 2009, 63, 711-724. [CrossRef]

55. Bayham, F.E. Factors influencing the Archaic pattern of animal utilization. Kiva 1979, 44, 219-235. [CrossRef]

56. Ugan, A.; Bright, J. Measuring foraging efficiency with archaeological faunas: The relationship between relative abundance indices and foraging returns. J. Archaeol. Sci. 2001, 28, 1309-1321. [CrossRef]

57. Nagaoka, L. The effects of resource depression on foraging efficiency, diet breadth, and patch use in southern New Zealand. J. Anthropol. Archaeol. 2002, 21, 419-442. [CrossRef]

58. Steadman, D.W.; Jones, S. Long-term trends in prehistoric fishing and hunting on Tobago, West Indies. Lat. Am. Antiq. 2006, 17, 316-334. [CrossRef]

59. Morrison, A.; Addison, D.J. Examining causes and trends in marine trophic level change: 1500 years of fish exploitation at Fatu-ma-Futi, Tutuila Island, American Sāmoa. J. Isl. Coast. Archaeol. 2009, 4, 177-194. [CrossRef]

60. Reitz, E.J. Fishing down the food web: A case study from St. Augustine, Florida, USA. Am. Antiq. 2004, 69, 63-83. [CrossRef]

61. Hardt, M.J. Lessons from the past: The collapse of Jamaican coral reefs. Fish Fish. 2009, 10, 143-158. [CrossRef]

62. Abbott, R.T.; Morris, P.A. Shells of the Atlantic and Gulf Coasts and the West Indies; Houghton Mifflin: Boston, MA, USA, 1995.

63. Bellwood, D.R. A phylogenetic study of the parrotfishes family Scaridae (Pisces: Labroidei), with a revision of genera. Rec. Aust. Mus. 1994, 20, 1-86. [CrossRef]

64. Froese, R.; Pauly, D. FishBase. Version (12/2020). 2020. Available online: www.fishbase.org (accessed on 13 June 2021).

65. Chambers, K. 1000 Years of Tuna (Scombridae: Thunnini) Exploitation at Sabazan, Carriacou, West Indies: Size Change and Sustainability through Time. Bachelor's Thesis, School of Social Science, University of Queensland,, Brisbane St. Lucia, Australia, 2017.

66. Keegan, W.F. The ecology of Lucayan Arawak fishing practices. Am. Antiq. 1986, 51, 816-825. [CrossRef]

67. Fritz, S.C.; Björck, S.; Rigsby, C.A.; Baker, P.A.; Calder-Church, A.; Conley, D.J. Caribbean hydrological variability during the Holocene as reconstructed from crater lakes on the island of Grenada. J. Quat. Sci. 2011, 26, 829-838. [CrossRef]

68. Gischler, E.; Shinn, E.A.; Oschmann, W.; Fiebig, J.; Buster, N.A. A 1500-Year Holocene Caribbean climate archive from the Blue Hole, Lighthouse Reef, Belize. J. Coast. Res. 2008, 246, 1495-1505. [CrossRef]

69. Malaizé, B.; Bertran, P.; Carbonel, P.; Bonnissent, D.; Charlier, K.; Galop, D.; Imbert, D.; Serrand, N.; Stouvenot, C.; Pujol, C. Hurricanes and climate in the Caribbean during the past 3700 years BP. Holocene 2011, 21, 911-924. [CrossRef]

70. Richey, J.N.; Poore, R.Z.; Flower, B.P.; Quinn, T.M. 1400 yr multiproxy record of climate variability from the northern Gulf of Mexico. Geology 2007, 35, 423-426. [CrossRef] 
71. Cobb, K.M.; Charles, C.D.; Cheng, H.; Edwards, R.L. El Niño/Southern Oscillation and tropical Pacific climate during the last millennium. Nature 2003, 424, 271-276. [CrossRef]

72. Eakin, C.M.; Morgan, J.A.; Heron, S.F.; Smith, T.B.; Liu, G.; Alvarez-Filip, L.; Baca, B.; Bartels, E.; Bastidas, C.; Bouchon, C.; et al. Caribbean corals in crisis: Record thermal stress, bleaching, and mortality in 2005. PLoS ONE 2010, e13969. [CrossRef]

73. Emanuel, K. Increasing destructiveness of tropical cyclones over the past 30 years. Nature 2005, 436, 686-688. [CrossRef] [PubMed]

74. Gill, J.A.; Watkinson, A.R.; McWilliams, J.P.; Côté, I.M. Opposing forces of aerosol cooling and El Niño drive coral bleaching on Caribbean reefs. Proc. Natl. Acad. Sci. USA 2006, 103, 18870-18873. [CrossRef]

75. Saunders, M.A.; Lea, A.S. Large contribution of sea surface warming to recent increase in Atlantic hurricane activity. Nature 2008, 451, 557-560. [CrossRef]

76. Grouard, S. Faunal remains associated with Late Saladoïd and Post- Saladoïd occupations at Anse à la Gourde, Guadeloupe, West Indies: Preliminary results. Archaeofauna 2001, 10, 71-98.

77. Lambrides, A.B.; McNiven, I.J.; Ulm, S. Meta-analysis of Queensland's coastal Indigenous fisheries: Examining the archaeological evidence for geographic and temporal patterning. J. Archaeol. Sci. Rep. 2019, 28, 102057. [CrossRef]

78. McKechnie, I.; Moss, M.L. Meta-analysis in zooarchaeology expands perspectives on Indigenous fisheries of the Northwest Coast of North America. J. Archaeol. Sci. Rep. 2016, 8, 470-485. [CrossRef]

79. McKechnie, I. Investigating the complexities of sustainable fishing at a prehistoric village on western Vancouver Island, British Columbia, Canada. J. Nat. Conserv. 2007, 15, 208-222. [CrossRef]

80. Olsson, L.; Jerneck, A.; Thoren, H.; Persson, J.; O’Byrne, D. Why resilience is unappealing to social science: Theoretical and empirical investigations of the scientific use of resilience. Sci. Adv. 2015, 1, e1400217. [CrossRef]

81. Marshall, K.N.; Levin, P.S. When “sustainable" fishing isn't. In Effective Conservation Science: Data Not Dogma; Kareiva, P., Marvier, M., Silliman, B., Eds.; Oxford University Press: Oxford, UK, 2018; pp. 110-114. [CrossRef]

82. Pauly, D.; Christensen, V.; Guénette, S.; Pitcher, T.J.; Sumaila, U.R.; Walters, C.J.; Watson, R.; Zeller, D. Towards sustainability in world fisheries. Nature 2002, 418, 689-695. [CrossRef] [PubMed]

83. Salas, S.; Chuenpagdee, R.; Charles, A.; Seijo, J.C. (Eds.) Coastal Fisheries of Latin America and the Caribbean; FAO Fisheries and Aquaculture Technical Paper No. 544; FAO: Rome, Italy, 2011.

84. Boivin, N.; Crowther, A. Mobilizing the past to shape a better Anthropocene. Nat. Ecol. Evol. 2021, 5, 273-284. [CrossRef] [PubMed]

85. Holtorf, C. Embracing change: How cultural resilience is increased through cultural heritage. World Archaeol. 2018, 50, 639-650. [CrossRef]

86. Chislett, G.R. Comparative Aspects of the Ecology of Three Nerita (Molluska: Gastropoda), Species from Different Locations in Barbados. Master's Thesis, McGill University, Montreal, QC, Canada, 1969.

87. Food an Agricultural Organization. The Sustainable Intensification of Caribbean Fisheries and Aquaculture; I3932E/1/07.14; Food an Agricultural Organization of the United Nations, 2014; Available online: http:/ / www.fao.org/3/i3932e/i3932e.pdf (accessed on 13 June 2021).

88. Bouchon, C.; Portillo, P.; Bouchon-Navaro, Y.; Louis, M.; Hoetjes, P.; De Meyer, K.; Macrae, D.; Harding, S.; Mallela, J.; Parkinson, R.; et al. Status of coral reefs of the Lesser Antilles: The French West Indies, The Netherlands Antilles, Anguilla, Antigua, Grenada, Trinidad and Tobago. In Status of Coral Reefs of the World; Wilkinson, C., Ed.; Global Coral Reef Monitoring Network and Reef and Rainforest Research Centre: Townsville, Australia, 2008; pp. 265-280.

89. Jackson, J.B.C.; Donovan, M.K.; Cramer, K.L.; Lam, V.V. (Eds.) Status and Trends of Caribbean Coral Reefs: 1970-2012; Global Coral Reef Monitoring Network, IUCN: Gland, Switzerland, 2014.

90. Morris, J.A., Jr. (Ed.) Invasive Lionfish: A Guide to Control and Management; Gulf and Caribbean Fisheries Institute Special Publication Series Number 1: Marathon, FL, USA, 2012. [CrossRef]

91. van Tussenbroek, B.I.; Arana, H.A.H.; Rodríguez-Martínez, R.E.; Espinoza-Avalos, J.; Canizales-Flores, H.M.; González-Godoy, C.E.; Barba-Santos, M.G.; Vega-Zepeda, A.; Collado-Vides, L. Severe impacts of brown tides caused by Sargassum spp. on near-shore Caribbean seagrass communities. Mar. Pollut. Bull. 2017, 122, 272-281. [CrossRef] [PubMed]

92. Rivera, A.; San Martin-Chicas, J.; Myton, J. Transitioning to co-management in Caribbean reef fisheries: Tela Bay case study. Sustain. Sci. 2021, 16, 1233-1250. [CrossRef] 